\title{
抗体医薬の創薬から承認まで
}

\author{
坂中千恵 ${ }^{\dagger}$
}

\section{Antibody Therapeutics: Bench to Bedside}

\author{
Chie Sakanaka ${ }^{\dagger}$ \\ Pharmaceuticals and Medical Devices Agency (PMDA); 3-3-2 Kasumigaseki, \\ Chiyoda-ku, Tokyo 100-0013, Japan.
}

(Received October 22, 2016)

\begin{abstract}
Monoclonal antibodies have been considered promising therapeutic entities due to their highly specific binding to antigens. For oncology in particular, the tumor specific binding of an antibody, without affecting normal tissue, is considered an ideal cancer therapy. Although the proposed mechanism of action of antibody therapeutics varies by targets and indications, antibody-dependent cytotoxicity (ADCC), complement-dependent cytotoxicity (CDC), ligand neutralization and inhibition of the signaling pathway are commonly used. Recent advances in genomic information, genetic engineering, and transgenic technology have greatly accelerated drug development processes. It is also possible to add new functions to antibody molecules through molecular engineering. For example, antibody-drug conjugates (ADC), which combine a monoclonal antibody and a small-molecule cytotoxic drug, have been successfully used for cancer treatment. It has been more than 20 years since the first therapeutic antibody was approved in Japan, and there are now more than 30 antibodies on the market, with many new molecules under development. Despite some drawbacks and challenges, antibody therapeutics hold great promise as we advance our knowledge and technologies in the coming years.
\end{abstract}

Key words—— monoclonal antibody; antibody therapeutics; drug development; regulatory approval

\section{はじめに}

抗体医薬は，抗原に対する親和性の強さと特異性 の高さという抗体分子の持つ特徴から, 分子標的薬 の 1 つとしての可能性が注目され, 様々な疾患に対 して開発が進んでいる。特に腫瘍細胞特異的な作用 への期待から，抗がん剂としての開発が多い.さら に, ゲノム情報の充実, 遺伝子工学, 遺伝子改変動 物作製技術などの科学技術の革新的な進歩が，適切 な標的分子の探索，抗体のヒト化，高機能性抗体分 子の作製，ハイスループットのスクリーニングな ど，医薬品開発のあらゆるステージでのスピード アップを支えている. また，こうした技術的な進歩 により，抗原の中和，結合分子の機能阻害，抗体依

独立行政法人医薬品医療機器総合機構（干100-0013 東 京都千代田区霞が関 3-3-2)

現所属: †東京大学医学部附属病院臨床研究支援セン 夕一（†113-8655 東京都文京区本郷 7-3-1)

e-mail: sakanaka-chie@umin.org

本総説は, 日本薬学会第 136 年会シンポジウム S18 で 発表した内容を中心に記述したものである。
存性細胞傷害作用 (antibody-dependent cell-mediated cytotoxicity; ADCC) や補体依存性細胞傷害作 用 (complement-dependent cytotoxicity; CDC) と いつた抗体本来の有する機能に加えて，新たな作用 機序を抗体医薬に持たせることも可能になってき た．抗体に細胞傷害性のある低分子化合物を結合さ せた，抗体薬物複合体 (antibody drug conjugates; ADC）はその一例である。わが国で最初の抗体医 薬が承認されてから 20 年以上がたち, 現在 30 品目 近い抗体医薬品が承認されている。開発中の薬剤も 多数あり，抗体技術の進歩と相まって，抗体医薬品 の臨床使用が増えていくと思われる.

\section{抗体医薬の特徵}

抗体医薬の特徴として，まず抗体分子そのものが 有する, 抗原分子への高い結合性と特異性が挙げら れる，抗体は，生体内に自然に存在する分子であ り, その本来の機能を利用したり, あるいは分子改 変技術を用いて新たな機能を付け加えたりすること が可能である. また抗体医薬品の標的分子として は, 受容体などの細胞膜表面タンパクのほかに, リ 
ガンド，ウイルス抗原，細菌性抗原，薬物など多様 であり，作用機序も，ADCC, CDC，抗原中和作 用，シグナル伝達阻害作用など様々で対象疾患も多 岐にわたる．さらに分子改変により，Fab 断片や， $\mathrm{ADC}$ ，多重特異性抗体の作製なども可能であり， 臨床応用範囲の拡大が期待される.

\section{既承認の抗体医薬}

現在（2016 年 3 月時点），日米欧で 48 の治療用 抗体が承認，販売されており，その内訳は，日本 32, 欧州 43, 米国 45 となっている. 48 抗体のう ち, 25 品目が抗悪性腫瘍薬であり, 次に多いのは 免疫関連の疾患となっている. 悪性腫瘍以外の適応 としては関節リウマチ，乾癬，多発性硬化症，喘 息，全身性エリテマトーデス（systemic lupus erythematosus; SLE)，骨病変，加齢黄斑変性，RS ウイルス感染，炭疽，高コレステロール血症などが ある。

日米欧で既承認の抗体医薬をまとめた表を示す (Table 1).

\section{抗体医薬の標的}

抗体医薬の開発において, 標的の選択は非常に重 要なポイントであり，標的の機能，各組織や対象疾 患での発現状況などの情報が有用となる．抗体医薬 は細胞内の分子を標的にすることは困難なため，受 容体，リガンドなどの細胞膜表面上のタンパクが主 な標的となっている。また，血中のリガンド （TNF，IL-6, VEGF など）や，細菌抗原（炭疽菌） も標的となり得る. 生物分子以外も抗体の抗原とな るため，例えば抗凝固薬である dabigatran に対す る抗体は，速やかに dabigatran の抗凝固作用を中 和し止血機能を回復できる中和剤 (いわゆる解毒剂) として用いられている.

疾患の発症や進行に重要な分子やシグナル経路に 対しては，同一分子を標的とする抗体 (CD20, PD1，EGFR など）や，同一シグナル経路の異なる 分子を標的とした抗体 (VEGF と VGEFR, PD-1 と PD-L1 など）が作製されている. 同じ標的，同じ シグナル経路に対する抗体であっても，アミノ酸配 列が異なり生物学的特性は異なるため, 同一の作用 が得られるとは限らない。

\section{抗体医薬の作用機序}

上述したように抗体医薬は様々な標的分子に結合 し，作用機序も多様であるが，大きくは，抗体本来
の作用を用いた機序と，分子改変などによる新規の 機序に分けられる．抗体本来の作用を用いた機序に は，抗体分子の補体や Fc 受容体への結合による $\mathrm{ADCC}$ 及び CDC という細胞傷害活性がある。この 作用機序は多くの抗腫瘍抗体薬で用いられている. また，抗原に対する高い親和性により，標的分子と その結合パートナー分子の結合阻害や標的分子の中 和作用を介して, 細胞内シグナル伝達を阻害し生体 機能の調節や抑制を起こすことが可能である．細胞 増殖因子受容体（VEGFR, EGFR など）に対する 抗体やリガンドに対する中和抗体などが含まれる. また，抗体分子の改変により，作用の増強や新規機 序の作用を付加する試みも進んでいる，例えば抗体 分子に結合している糖鎖を改変することにより, ADCC 作用を増強した抗体 mogamulizumab が作製 されている．また近年，HER2 に対する抗体に細胞 傷害性薬剂を結合させた ADC, trastuzumab emtansine が, 同じ標的に対する既存の抗体 (trastuzumab) に耐性となった症例にも有効性を示して注目され， 今後も開発が進む分野と考えられる.

抗体のフォーマット

抗体のフォーマットもテクノロジーの進歩により 変化してきている，過去にはマウスモノクローナル 抗体も臨床使用されており，ヒトでの異種タンパク に対する免疫反応による有害事象が問題であった が，その後マウス抗体とヒト抗体のハイブリッドで あるマウス／ヒトのキメラ抗体が主流となった。た だしキメラ抗体にも，一部マウス抗体のアミノ酸配 列が含まれているため，異種反応の懸念があり，最 近ではヒト化抗体，さらにファージディスプレイを 用いたヒト型抗体やトランスジェニックマウスによ るヒト型抗体が主流となってきている（Tables 1 and 2). 抗体のサブクラスについては，補体結合性 や Fc 受容体親和性の高い IgG1 が主流ではある が，そうした機能を持たないことが利点となり得る $\mathrm{IgG} 2$ や IgG4 抗体も使われている. ${ }^{1)}$ また， IgG4 抗 体は，Fab のアーム交換が起こることによる抗原特 異性の変化が懸念されていたが，S228P 変異を導入 することにより，分子が安定化しアーム交換が阻害 されることが示され, ${ }^{2)}$ 多くの IgG4 抗体で S228P 変異が用いられている。

\section{抗体医薬の安全性}

抗体医薬は，抗原特異性が高いため，標的以外へ 
Table 1. Approved Antibody Therapeutics (As of March 2016)

\begin{tabular}{|c|c|c|c|c|c|c|}
\hline \multirow{2}{*}{ Brand name (INN) } & \multicolumn{3}{|c|}{ Approval year $\left(^{*}:\right.$ withdrawn) } & \multirow{2}{*}{ Target } & \multirow{2}{*}{ Format } & \multirow{2}{*}{ Indication } \\
\hline & US & EU & JPN & & & \\
\hline MabThera, Rituxan (Rituximab) & 1997 & 1998 & 2001 & CD20 & Chimeric IgG1 & Cancer \\
\hline Herceptin (trastuzumab) & 1998 & 2000 & 2001 & HER2 & Humanized IgG1 & Cancer \\
\hline Zevalin (ibritumomab tiuxetan) & 2002 & 2004 & 2008 & CD20 & Murine IgG1 & Cancer \\
\hline Erbitux (cetuximab) & 2004 & 2004 & 2008 & EGFR & Chimeric IgG1 & Cancer \\
\hline Avastin (bevacizumab) & 2004 & 2005 & 2007 & VEGF & Humanized IgG1 & Cancer \\
\hline Vectibix (panitumumab) & 2006 & 2007 & 2010 & EGFR & Human IgG2 & Cancer \\
\hline Arzerra (ofatumumab) & 2009 & 2010 & 2013 & CD20 & Human IgG1 & Cancer \\
\hline Yervoy（ipilimumab) & 2011 & 2011 & 2015 & CTLA-4 & Human IgG1 & Cancer \\
\hline Adcetris (brentuximab vedotin) & 2011 & 2012 & 2014 & CD30 & Chimeric IgG1 & Cancer \\
\hline Perjeta (pertuzumab) & 2012 & 2013 & 2013 & HER2 & Humanized IgG1 & Cancer \\
\hline Kadcyla (ado-trastuzumab emtansine) & 2013 & 2013 & 2013 & HER2 & Humanized IgG1 & Cancer \\
\hline Gazyva (obinutuzumab) & 2013 & 2014 & NA & CD20 & Humanized IgG1 & Cancer \\
\hline Cyramza (ramucirumab) & 2014 & 2014 & 2015 & VEGFR2 & Human IgG1 & Cancer \\
\hline Opdivo (nivolumab) & 2014 & 2015 & 2014 & PD1 & Human IgG4 & Cancer \\
\hline Keytruda (pembrolizumab) & 2014 & 2015 & in review & PD1 & Humanized IgG4 & Cancer \\
\hline Blincyto（blinatumomab） & 2014 & 2015 & NA & CD19, CD3 & $\begin{array}{l}\text { Murine bispecific } \\
\text { tandem scFv }\end{array}$ & Cancer \\
\hline Unituxin (dinutuximab) & 2015 & 2015 & NA & GD2 & Chimeric IgG1 & Cancer \\
\hline Portrazza (necitumumab) & 2015 & 2016 & NA & EGFR & Human IgG1 & Cancer \\
\hline Darzalex (daratumumab) & 2015 & in review & NA & CD38 & Human IgG1 & Cancer \\
\hline Empliciti (elotuzumab) & 2015 & NA & in review & CS1 (SLAMF7) & Humanized IgG1 & Cancer \\
\hline Mylotarg (gemtuzumab ozogamicin) & $2000^{*}$ & NA & 2005 & CD33 & Humanized IgG4 & Cancer \\
\hline Lemtrada (alemtuzumab) & $2001^{*}, 2014$ & 2013 & 2014 & CD52 & Humanized IgG1 & Cancer \\
\hline Removab (Catumaxomab) & NA & 2009 & NA & EPCAM/CD3 & $\begin{array}{c}\text { Rat/mouse } \\
\text { bispecific mAb }\end{array}$ & Cancer \\
\hline Poteligeo (mogamulizumab) & NA & NA & 2012 & CCR4 & Humanized IgG1 & Cancer \\
\hline Prolia, Xgeva (denosumab) & 2010 & 2010 & 2012 & RANK-L & Human IgG2 & Bone loss, Cancer \\
\hline Simulect (Basiliximab) & 1998 & 1998 & 2002 & IL-2R & Chimeric IgG1 & Autoimmune \\
\hline Humira (adalimumab) & 2002 & 2003 & 2008 & TNF & Human IgG1 & Autoimmune \\
\hline Xolair (omalizumab) & 2003 & 2005 & 2009 & $\operatorname{IgE}$ & Humanized IgG1 & Autoimmune \\
\hline Tysabri (natalizumab) & 2004 & 2006 & 2014 & a4 integrin & Humanized IgG4 & Autoimmune \\
\hline Stelara（ustekinumab） & 2008 & 2009 & 2011 & IL-12/23 & Human IgG1 & Autoimmune \\
\hline Cimzia (certolizumab pegol) & 2008 & 2009 & 2012 & TNF & Humanized Fab & Autoimmune \\
\hline Simponi (golimumab) & 2009 & 2009 & 2011 & TNF & Human IgG1 & Autoimmune \\
\hline Actemra（tocilizumab) & 2010 & 2009 & 2005 & IL-6R & Humanized IgG1 & Autoimmune \\
\hline Benlysta (belimumab) & 2011 & 2011 & NA & BLyS & Human IgG1 & Autoimmune \\
\hline Entyvio (vedolizumab) & 2014 & 2014 & NA & $\alpha 4 \beta 7$ integrin & Humanized IgG1 & Autoimmune \\
\hline Cosentyx (secukinumab) & 2015 & 2015 & 2014 & IL-17a & Human IgG1 & Autoimmune \\
\hline Nucala (Mepolizumab) & 2015 & 2015 & NA & IL-5 & Humanized IgG1 & Autoimmune \\
\hline Remicade (infliximab) & 1998 & 1999 & 2002 & TNF & Chimeric IgG1 & Autoimmne \\
\hline Repatha (evolocumab) & 2015 & 2015 & 2016 & PCSK9 & Human IgG2 & Metabolic \\
\hline Praluent (alirocumab) & 2015 & 2015 & in review & PCSK9 & Human IgG1 & Metabolic \\
\hline Soliris (eculizumab) & 2007 & 2007 & 2010 & $\mathrm{C} 5$ & Humanized IgG2/4 & Genetic disease \\
\hline Ilaris (canakinumab) & 2009 & 2009 & 2011 & IL- $1 \beta$ & Human IgG1 & Genetic disease \\
\hline Sylvant (siltuximab) & 2014 & 2014 & NA & IL-6 & Chimeric IgG1 & Genetic disease \\
\hline Lucentis (ranibizumab) & 2006 & 2007 & 2009 & VEGF & Humanized IgG1 Fab & Eye disease \\
\hline Praxbind (idarucizumab) & 2015 & 2015 & NA & Dabigatran & Humanized Fab & Antidote \\
\hline Synagis (Palivizumab) & 1998 & 1999 & 2002 & RSV & Humanized IgG1 & Anti-virus \\
\hline Reopro (Abciximab) & 1994 & 1995 & NA & GPIIb/IIIa & Chimeric IgG1 Fab & Anti-platelet \\
\hline Abthrax (raxibacumab) & 2012 & NA & NA & B. anthracis $\mathrm{PA}$ & Human IgG1 & Anti-bacteria \\
\hline
\end{tabular}


Table 2. Format of Antibody Therapeutics

\begin{tabular}{c|c|c}
\hline \hline Antibody format & Subtype & $n$ \\
\hline Human IgG & & 17 (Total) \\
\hline & IgG1 & 13 \\
\hline & IgG2 & 3 \\
\hline Humanized IgG & IgG4 & 1 \\
\hline & IgG1 & 13 \\
\hline & IgG2/4 & 1 \\
\hline & IgG4 & 3 \\
\hline Human/Mouse Chimera & & 8 (including 1 Fab) \\
\hline Mouse/Rat Chimera & & 1 \\
\hline Mouse IgG & & 2 \\
\hline
\end{tabular}

の作用が少ないと考えられ，副作用がより少ないと 謳われる場合も多い。しかしながら，予測性の有無 にかかわらず薬剤の投与による副作用・有害事象は 起こり得る. 2006 年に英国での FIH 試験で発生し た重篤な有害事象は，早期臨床試験実施施設のみな らず，抗体医薬開発現場に大きな衝撃を与えた。本 件では, CD28 分子に対するアゴニスト抗体,

TGN1412 が投与された健常成人男性被験者に，呼 吸器症状, 多臓器不全, 血管浮腫を伴う全身の炎症 反応，いわゆるサイトカインストームが発現し，実 薬が投与された 6 名全員が ICU での管理を受ける こととなった。この事例を受けて，ヒト初回投与量 の設定にあたっては，従来から用いられていた無毒 性量 (no-observed adversed event level; NOAEL) だけではなく, 推定最小薬理作用量 (minimum anticipated biological effect level; MABEL) も検討す ることを勧めるガイドラインが European Medicines Agency (EMA) から発出された. ${ }^{3)}$

健常人対象の第 $\mathrm{I}$ 相試験の結果は公表されない場 合も多く，情報は限られるが，論文などを基に抗体 医薬品の第 $\mathrm{I}$ 相試験の安全性を調査した研究による と, 生命を脅かす有害事象が発現するリスクは 425-1700人の被験者あたり 1 例と推定されてい る. そして，この推定の基となった生命を脅かす有 害事象のすべては上述した TGN1412 試験によるも のであり，他の抗体薬の試験では認められていな かった. ${ }^{4)}$
Table 3. PML due to Antibody Therapeutics

\begin{tabular}{c|c|c|c}
\hline \hline Antibody & Format & Target & PML \\
\hline rituximab & chimera & CD20 & unknown \\
\hline basiliximab & chimera & CD25 & unknown \\
\hline bevasilizimab & humanized & VEGF & $<0.1 \%$ \\
\hline ofatumumab & human & CD20 & $0.40 \%$ \\
\hline brentuximab vedotin & chimera & CD30 & unknown \\
\hline alemtuzumab & humanized & CD52 & unknown \\
\hline natalizumab & humanized & $\alpha 4$ integrin & $0.40 \%$ \\
\hline ramcirumab & human & VEGFR2 & unknown \\
\hline
\end{tabular}

\section{抗体医薬の副作用}

抗体医薬の副作用として，まず抗体の作用機序に 関連した作用が挙げられる。例えば，免疫系に作用 する抗体薬による免疫抑制, 感染症, 血球減少や過 剰な免疫反応（免疫関連有害事象）などがある，免 疫抑制作用によるものとして，問題となった副作用 の 1 つに進行性多巣性白質脳症（progressive multifocal leukoencephalopathy; PML）がある。これ は，免疫抑制状態となった人において，JCウイル スが再活性し, 進行性かつ致死性の脳内病変がおこ る疾患である。現在のところ治療法はなく，わが国 では難病に指定されている，JCウイルスは健常人 に対しては全く問題がないが，HIV 感染者での発 症は 1000 人あたり 1-3 人と高頻度である. 近年, 抗体医薬の使用中に PML の発症が報告されてお り, 注意が必要である(Table 3).5) 反対に免疫の 活性化により起こる免疫関連有害事象は, 最近登場 したがんに対する免疫チェックポイント阻害剤によ る, 全身の各臓器に多様な作用を及ぼす特徵的な副 作用として注目されている.

また抗体の標的に関係する作用としては，HER2 に対する抗体による心障害, VEGFR に対する抗体 による出血, 血栓・塞栓症, EGFR に対する抗体 による皮膚障害がある。EGFR 阻害による皮膚障 害は, 皮膚に発現している EGFR に抗体が結合し て起こると考えられており, 抗体以外の EGFR 阻 害剂でもみられる。皮膚障害と薬剤の有効性には関 連があるとされ, 皮膚障害の発現が予測される薬理 作用を発揮していることの裏付けとも言えるため, 対応は十分に検討する必要がある.

抗体医薬ではよく知られているインフュージョン 
Table 4. Infusion Reaction due to Approved Antibody Therapeutics

\begin{tabular}{|c|c|c|}
\hline Antibody & Format & \begin{tabular}{|c} 
Infusion Reaction \\
(Japanese Package \\
Insert)
\end{tabular} \\
\hline rituximab & $\begin{array}{c}\text { mouse/ } \\
\text { human chimera }\end{array}$ & 〜90\% \\
\hline inflixiab & $\begin{array}{c}\text { mouse/ } \\
\text { human chimera }\end{array}$ & unknown \\
\hline cetuximab & $\begin{array}{c}\text { mouse/ } \\
\text { human chimera }\end{array}$ & $<0.5-10 \%$ \\
\hline brentuximab vedotin & $\begin{array}{c}\text { mouse/ } \\
\text { human chimera }\end{array}$ & $11 \%$ \\
\hline trastuzumab & humanized & $\sim 40 \%$ \\
\hline gemtuzumab ozogamicin & humanized & $47.90 \%$ \\
\hline bevacizumab & humanized & unknown \\
\hline eculizumab & humanized & unknown \\
\hline panitumumab & human & $<1 \%$ \\
\hline mogamulizumab & humanized & $58.80 \%$ \\
\hline ofatumumab & human & $49.80 \%$ \\
\hline trastuzumab emtansine & humanized & $1.20 \%$ \\
\hline pertuzumab & humanized & $8.80 \%$ \\
\hline alemtuzumab & humanized & $96.90 \%$ \\
\hline nivilmab & human & unknown \\
\hline ipilimumab & human & $1 \%$ \\
\hline ramucirumab & human & $0.40 \%$ \\
\hline
\end{tabular}

リアクション（infusion reaction, infusion-related reaction，投与時反応）は，薬剤，特に分子標的薬 の静脈内投与に伴って起こる免疫関連反応である.

多くの場合，薬剤投与から 30 分 -2 時間以内に発現 し，初回投与時に起こることが多いが，2 回目以降 の投与時に起こる場合もある. 症状は，顔面紅潮， 心拍数増加, 血圧変化, 呼吸困難, 気道攣縮, 背部 痛，発熱，掻痒，浮腫，吐気，発赤等の全身反応と して現れる.アナフィラキシー，アレルギー反応と して発症することもあり, 注意が必要である。軽度 の infusion reaction は，薬剤の投与中断や投与時間 の変更，予防的な前投薬（抗ヒスタミン剂，消炎鎮 痛剂，ステロイド剂など）の投与により軽減するこ とが可能である. ${ }^{6}$ 既承認の抗体薬の infusion reactionの頻度を，日本の添付文書の記載を基にまとめ た (Table 4). キメラ抗体である rituximab では, 非常に頻度が高く前投与が必要とされているが，同 じキメラ抗体であっても発現頻度の低い抗体もある
一方，ヒ卜抗体であっても高頻度で infusion reaction が認められているものもあり，異種反応が原因 であると結論づけることは難しく，現在でもその発 現機序の詳細は不明である.

抗体医薬の副作用は，ときに全身性の重篤な障害 を惹起する場合もあり，使用時には薬剤のリスクと ベネフィットを検討しつつ, 中断・減量といつた判 断を行う必要がある.

\section{最後に}

1980 から 2000 年の間に 186 の抗体医薬が治験に 入り，10 品目が承認された. ${ }^{7)}$ 現在，約 500 の抗体 が治験中であり，うち 80 近くが開発の後期の相に ある (Thomson Routers Integrity による)。今後も さらに臨床現場で使用される抗体医薬は増えていく と考えられる，その作用機序，標的の多様性に加え て，技術革新や新しいアイデアによる，革新的な抗 体医薬の登場を期待したい.

利益相反＼cjkstart開示すべき利益相反はない.

\section{REFERENCES}

1) Salfeld J. G., Nat. Biotechnol., 25, 1369-1372 (2007).

2) van der Neut Kolfschoten M., Schuurman J., Losen M., Bleeker W. K., Martinez-Martinez P., Vermeulen E., den Bleker T. H., Wiegman L., Vink T., Aarden L. A., De Baets M. H., van de Winkel J. G., Aalberse R. C., Parren P. W., Science, 317, 1554-1557 (2007).

3) European Medicines Agency, Committee for Medical Products for Human Use (CHMP). "Guideline on Strategies to Identify and Mitigate Risks for First-in Human Clinical Trials with Investigational Medical Products.": 〈http:// www.ema.europa.eu / docs/en_GB/document_library/Scientific guideline/2009/09/WC500002988.pdf $\rangle$, cited 25 September, 2016.

4) Tranter E., Peters G., Boyce M., Warrington S., Br. J. Clin. Pharmacol., 76, 164-172 (2013).

5) Health Labour Sciences Research Grant, Research on Measures for Intractable Diseases, Prion-byo oyobi chihatusei uirusukansensho ni kansuru chosakenkyuhan. "Progressive multifocal leukoencephalopathy 
Clinical Practice Guideline 2013".

6) LaCasce A. S., Castells M. C., Burstein H., Meyerhardt J. A., "Infusion reactions to therapeutic monoclonal antibodies used for cancer therapy.": 〈http://www.uptodate.com/con tents / infusion-reactions-to-therapeutic-mono clonal-antibodies-used-for-cancer-therapy, UpToDate ${ }^{\circledR}$, cited 25 September, 2016.

7) Reichert J. M., Nat. Biotechnol., 19, 819-822 (2001). 